\title{
DUALISME ABORTUS PROVOCATUS DALAM PERSPEKTIF REGULASI (PERUNDANG-UNDANGAN) DI INDONESIA
}

\author{
Ahmad Syakirin, S. H., M. H. \\ Institut Agama Islam Negeri Ponorogo \\ ahmadsyakiringamma@gmail.com
}

\begin{abstract}
Perkembangan pola kehidupan masyarakat yang semakin cepat memberikan berbagai dampak positif ataupun negatif dari berbagai sudut pandang. Pergaulan bebas tanpa dilandasi dengan tatanan ilmu dan moral akan menjadi menjadikan rusaknya tatanan kehidupan tanpa melihat lagi norma-norma yang berlaku. Hubungan bebas atau free sex menjadi gaya hidup yang semakin bebas dikalangan remaja ataupun masyarakat, tentu hal ini memberikan imbas akibat terjadinya kehamilan yang tidak dikehendaki dimana pada akhirnya mengambil sebuah tindakan untuk melakukan aborsi atau mengugurkan janin yang ada dalam kandungan. Aborsi merupakan perbuatan dilarang dalam berbagai perundang-undangan yang ada di Indonesia serta mengancam dengan sanksi yang tegas dari tindakan pengguguran janin tersebut. Ada dua regulasi undang-undang yang keduanya sama-sama melarang tindakan aborsi ini, pertama terdapat pada Undang-Undang No 36 Tahun 2009 Tentang Kesehatan dan yang kedua terdapat pada Undang-Undag No 35 Tahun 2014 Tetang Perlindungan Anak. Sekalipun kedua undang-undang ini tidak memiliki nama yang sama akan tetapi mempunyai tujuan dan membawa misi serta ancaman penjatuhan sanksi pidana yang sama seperti terlihat dalam pasal-pasal kedua undang-undang tersebut mengatur. Dua pandangan (dualisme) berbeda yang terdpat dalam undang-undang memberikan petunjuk nantinya dalam menerapkan perbuatan tindak pidana pada pelaku aborsi. Ada beberapa hal yang diperbolehkan dalam larangan aborsi ini yakni indikasi kedaruratan medis apabila membahayakan bagi ibu yang mengandung dan kedua merupakan korban pemerkosaan. Penentuan larangan aborsi sebagaimana di payung hukumi kedua regulasi tersebut memberikan bukti bahwa adanya kehidupan ini dijamin serta di lindungi oleh negara.
\end{abstract}

\begin{abstract}
The development of the pattern of people's lives that are increasingly rapidly giving various positive or negative impacts from various perspectives. Free association without being based on the order of science and morals will cause damage to the order of life without looking at the prevailing norms. Free relationship or free sex is becoming an increasingly free lifestyle among teenagers or the community, of course this has an impact on the occurrence of unwanted pregnancies which in the end takes an action to have an abortion or abort the fetus in the womb. Abortion is an act that is prohibited in various laws in Indonesia and threatens with strict sanctions from the act of aborting the fetus. There are two legal regulations that both prohibit abortion, the first is in Law No. 36 of 2009 concerning Health and the second is contained in Law No. 35 of 2014 concerning Child Protection. Even though these two laws do not have the same name, they have a purpose and carry the same mission and threat of criminal sanctions as seen in the articles of the two laws that regulate. Two different views (dualism) contained in the law provide guidance later in applying criminal acts to abortionists. There are several things that are allowed in this abortion ban, namely an indication of a medical
\end{abstract}


emergency if it is dangerous for the pregnant mother and the second is a victim of rape. The determination of the prohibition of abortion as under the legal umbrella of the two regulations provides evidence that the existence of this life is guaranteed and protected by the state.

Keywords: Abortion, freedom, dualism, sanctions, regulation.

\section{PENDAHULUAN}

Kehidupan adalah anugrah dari Tuhan Yang Maha Esa. Setiap manusia memiliki hak hidup, bahkan sejak masih dalam kandungan. Dalam kasus lain mengandung adalah suatu yang berat, terlebih pada kehamilan akibat yang tidak dikehendaki. Terlepas pula dari alasan apapun yang menyebabkan terjadinya kehamilan tersebut, adanya abortus provocatus dilakukan karena terjadi kehamilan yang tidak di inginkan. Baik alasannya, dikarenakan kontrasepsi yang gagal, pemerkosaan, ekonomi, jenis kelamin, atau kehamilan diluar nikah. Alasan kuat melakukan aborsi adalah karena medis, sedangkan untuk korban pemerkosaan sudah masuk pada wilayah grey area (diperbolehkan).

Konstitusi neraga kita menjamin hak hidup yang erupakan hak asasi manusia sebagaimana tertuang pada pasal 28 B adalah hak untuk hidup. Di dalamnya berisi Undang-Undang Dasar 1945 yang berbunyi: "Setiap anak berhak atas kelangsungan hidup, tumbuh dan berkembang serta berhak atas perlindungan dari kekerasan dan diskriminasi". ${ }^{1}$ Dengan hak hidup, itu negara akan menjaga dan melindungi hak hidup setiap warganya, sehingga melalui alat penegak hukum mengharuskan bertindak apabila ada dan diketahui terjadi penghilangan hak hidup manusia.

Perpektif hukum yang ada Indonesia mengenai hak hidup, jika penghilangan hak hidup itu diancam maka tindakan negara akan memberikan hukuman yang berat sebagaimana diatur dalam KUHP, seperti halnya pembunuhan yang direncanakan terlebih dahulu, atau karena kelalaian yang menyebabkan matinya orang. Selain itu, hak reproduksi juga disinggung karena berkaitan erat dengan pengakuan hak asasi manusia bagi setiap pasangan atau individu untuk menentukan secara bebas dan bertanggung jawab mengenai jumlah anak, penjarakan anak, dan menentukan kelahiran anak mereka ${ }^{2}$.

Aborsi merupakan persoalan rentan terutama menyinggung tentang persoalan moral yang ada dimasyarakat serta hukum (sosio legal), secara umum dalam kehidupan berbangsa yang sangat kompleks. Aborsi merupakan cara yang paling sering digunakan mengakhiri kehamilan yang tidak diinginkan, tetapi juga cara yang paling berbahaya.

\footnotetext{
1 UUD 1945 menyatakan "setiap anak berhak atas kelangsungan hidup, tumbuh dan berkembang serta berhak atas perlindungan dari kekerasan dan diskriminasi".

2 Mien Rukmini, 2002. Laporan Akhir Penelitian Tentang Aspek Hukum Pelaksanaan Aborsi Akibat Perkosaan, Badan Pembinaan Hukum Nasional Departemen Kehakiman dan HAM, Jakarta, 67 Serta ditegaskan dalam undang-undang HAM No 39 Tahun 1999.
} 
Presentase angka aborsi di Indonesia terbilang cukup tinggi yakni menyentuh angka tidak kurang dari 2 juta kasus pertahunnya. Pola kehidupan yang semakin bebas menjadi salah satu indikator sebagai penyebab terjadinya kejahatan termasuk kejahatan aborsi ${ }^{3}$. Perbuatan pengguguran bakal janin yang ada kandungan sangat layak mendapatkan sanksi yang setimpal tanpa adanya alasan tertentu yang diperbolehkan. Akan tetapi alasan diatas acap kali tidak terpenuhi Karena berbagai faktor seperti lingkungan kehidupan yang bebas (free sex), kurangnya peran pengetahuan agama, ataupun faktor lainnya. Kebebasan inilah yang kemudian diterjemahkan secara bebas dalam berbagai hal tingkah laku, seperti kehidupan free sex alias kumpul kebo yang berakibat pada tingginya angka kehamilan yang tidak diinginkan, yakni ujungujungnya pada praktik angka aborsi semakin meningkat tajam. ${ }^{4}$

Praktek aborsi di Indonesia ini bukan hal yang baru saja terjadi, akan tetapi sudah menjadi fenomena yang menarik untuk dikupas dalam perspektif hukum. Tentu, dalam hal ini adalah pelaku perbuatan pengguguran kandungan, dimana sering ditangini seperti dokter, bidan, tenaga kesehatan, ataupun dukun bayi yang terlibat dalam proses pengguguran kandungan. Pihak-pihak seperti dikemukakan sangat berpotensi terkena jeratan delik aborsi yang berujung pada penjatuhan sanksi pidana.

Penggugguran kandungan (aborsi) sering kali menjadi perbicangan, baik pada forum-forum resmi maupun tidak resmi yang menyangkut bidang kedokteran, hukum maupun disiplin ilmu lainnya. Aborsi merupakan fenomena sosial yang semakin hari semakin memperihatinkan. Keprihatinan itu bukan tanpa alasan, karena sejauh ini perilaku pengguguran kandungan banyak menimbulkan efek negatif baik untuk diri pelaku maupun pada masyarakat luas. Hal ini disebabkan karena aborsi menyangkut norma moral serta hukum suatu kehidupan bangsa (sosio legal) ${ }^{5}$.

Pengguguran kandungan atau aborsi hakikatnya tidak bisa terlepas nilai-nilai ataupun norma yang berlaku dalam sebuah masyarakat. Dalam regulasi hukum pidana positif kita, tindakan aborsi telah diatur dalam KUHP yang tersebar diberbagai pasal, diantaranya pasal 299, 346, 348, 349, dan 350 KUHP memberikan definisi suatu bentuk kelahiran dini sebelum bayi itu pada waktunya dapat hidup sendiri diluar kandungan.

Menjalani kehamilan yang tidak diinginkan adalah suatau hal yang yang berat bagi korban pemerkosaan. Sudah menjadi korban pemerkosaan saja sudah berat apalagi jika ditambah lagi dengan adanya kehamilan dari hasil pemerkosaan tersebut. Hal ini dapat mengakibatkan korban akan terus dibayang-bayangi oleh peristiwa yangb menyababkan kehamilannya. Biasanya korban pemerkosaan akan mengalami dilematis

\footnotetext{
${ }^{3}$ Rukmini, Mien, 2002. Laporan Akhir Penelitian Tentang Aspek Hukum Pelaksanaan Aborsi Akibat Perkosaan, Badan Pembinaan Hukum Nasional Departemen Kehakiman dan HAM, Jakarta.

${ }^{4}$ Wayan Resmini, Pandaangan Norma Agama Dan Norma Hukum Tentang Aborsi. Jurnal Hukum Vol 4 No 2010. 25.

${ }^{5}$ Nasution, Khoiruddin. Pandangan Islam Tentang Aborsi. Musawa: Jurnal Studi Gender Dan Islam, Vol 2 (Yogyakarta: UIN Sunan Kalijaga Yogyakarta, 2003). Hal lain yang sering menjadi perhatian dalam diskusi-diskusi kecil dengan masyarakat yang memerlukan bantuan dan penyuluhan hukum yakni lembaga perlindungan hukum perempuan dan anak Ponorogo. Berbagai keluhan dan tindakan penanganan ataupun penyelesaian termasuk dalam memberi sosialisasi pada anak sekolah tentang sanski dan bahaya praktik aborsi.
} 
bila tetep meneruskan kehamilannya, ditambah lagi harus dihadapkan dengan persoalan bagaimana kedudukan dan nasib janin yang dikandungnya, bagaimana hukum atas anak yang dilahirkan yang dikarenakan kasus pemerkosaan tersebut. Tetapi bila korban tidak mengingkan kehamilan itu dengan jalan menggugurkan berati ia akan menjadi pelaku pembunuhan atas calon anaknya sendiri6.

Dalam dunia kedokteran, menggugurkan kandungan istilahnya adalah "abortus". Abortus atau yang lebih dikenal aborsi berati pengguguran kandungan atau membuang janin dengan sengaja sebelum waktunya. Salah satu masalah yang diatur dalam KUHP yang berlaku di Indonesia adalah masalah aborsi, dan saat ini telah diatur lebih lanjut dalam Undang-Undang Tentang Kesehatan Nomor 36 Tahun 2009. Wanita yang belum menikah ataupun yang sudah menikah bisa melakukan aborsi dengan beberapa alasan. Akan tetapi, korban yang melakukan aborsi biasanya melakukan aborsi dengan alasan utama adalah alasan non medis, yang sudah termasuk aborsi yang disengaja.

Adapun alasan lain korban melakukan aborsi adalah tidak ingin memiliki anak dikarenakan akan mengganggu karir, sekolah, atau tanggung jawab lain. Faktor ekonomi juga menjadi alasan yang lebih banyak ditemukan dan juga tepat, tidak memiliki cukup uang untuk merawat anak tanpa ayah. Apapun alasan yang dilakukan korban saat akan melakukan aborsi seorang wanita memiliki resiko yang sangat besar, resiko kesehatan dan keselamatan saat melakukan aborsi dan setelah melakukan aborsi salah satunya adalah kematian mendadak baik karena pendarahan hebat ataupun pembiusan yang gagal, infeksi disekitar kandungan, kerusakan leher rahim terjadi kecacatan, kanker, dan lain sebagainya.

Setiap tahunnya banyak perempuan menjalani kehamilan yang tidak diinginkan dan beberapa kehamilan berakhir dengan tindakan aborsi. menurut world health organisasion atau who, abortus adalah pengeluaran hasil konsepsi sebelum janin dapat hidup di luar kandungan dan sebagai batasan digunakan kehamilan kurang dari 20 minggu atau berat janin kurang dari 500 gram. aborsi bukan hal yang ringan untuk dilakukan. stigma sosial biasanya membayangi korban, hal inilah yang meyakinkan betapa seriusnya (pentingnya) praktik aborsi layak untuk menjadi bahan kajian kontemporer, serta masa kini targetnya yang merisaukan tertuju pada dominasi anakanak. apalagi di negera yang tidak melegalkan aborsi ini, berbagai aspek harus dipertimbangkan, baik dari aspek agama, moral, hukum, sampai pelayanan medis. adapun dalam aspek hukum, aborsi juga mengandung kontroversi. terlebih dalam masyarakat masih menuai pro dan kontra terkait praktek aborsi, dan hal inilah yang menjadi hal yang unik/menarik untuk dijadikan wacana dalam pembahasan nantinya. hal ini tentu

\footnotetext{
${ }^{6}$ Khoiruddin Nasution, 2003. Pandangan Islam Tentang Aborsi. Musawa: Jurnal Studi Gender Dan Islam, Vol 2 (Yogyakarta: UIN Sunan Kalijaga Yogyakarta), 33.
} 


\section{PEMBAHASAN}

Pengertian Aborsi (Abortus Provocatus)

Secara terminologi aborsi didefinisikan pengeluaran (secara paksa) janin dalam kandungan sebelum mampu hidup diluar kandungan, hal ini merupakan bentuk pembunuhan karena janin tidak diberi kesempatan untuk tumbuh di dalam kandungan.

Kata abortus berasal dari bahasa latin, jika di terjemahkan dalam bahasa Inggris yaitu abortion. Secara etimologis berarti, gugur kandungan atau keguguran ${ }^{7}$.

Aborsi dalam Kamus Besar Bahasa Indonesia aborsi adalah: 1). Terpancarnya embrio yang tidak mungkin lagi hidup sebelum habis bulan keempat dari kehamilan atau didefinisikan pengguguran janin atau embrio setelah melebihi masa dua bulan dari kehamilan. ${ }^{8}$ 2). Keadaan terhentinya pertumbuhan yang normal (untuk makhluk hidup). 3). Guguran (janin). Sardikin Gina Putra dari Fakultas Kedokteran UI menjelaskan secara terminologi mendefinisikan aborsi sebagai pengakhiran kehamilan sebelum janin dapat hidup di luar kandungan. Sedangkan menurut dokter R.S Samil dosen Fakultas Kedokteran Universitas Indonesia. Abortus adalah keguguran atau gugur kandungan yang berati berakhirnya kehamilan sebelum foetus dapat hidup sendiri diluar kandungan. Dikatakan sebgaai abortus jika fortus itu keluar dari kadungan sebelum 28 minggu hamil dan berat badan foetus yang keluar 1999 gram.

Perkembangan praktik aborsi dalam fenomena kehidupan saat ini justru semakin pesat. Hal ini tentu menjadi tantangan tersendiri baik bagi para penegak hukum sebagai perpanjangan tangan dari pemerintah untuk menegakkan tindakan ilegal ini. Angka tindakan ilegal terhadap aborsi ini terus meningkat setiap tahunnya, bahkan menyentuh angka hampir lebih 2000 pertahunnya ${ }^{9}$, justru ironisnya yang menjadi pelaksana tindakan aborsi ini adalah para tenaga medis, karena merakalah yang menguasai ilmu kedokteran pada kandungan. Kemudian tidak berhenti disitu, penyebab lain seperti pola kehidupan sex bebas menjadi biang kerok penyebab tindakan aborsi seperti ini.

Pada prinsipnya, perundang-undangan yang ada tidak menguraikan perbedaan pengertian mengenai pengguran kandungan atau membunuh kandungan, demikian pula tidak dijelaskan apa kandungan itu sendiri. Dari segi tata bahasa menggugurkan berarti membuat gugur atau menyebabkan gugur, dimana sama artinya dengan jatuh atau lepas. Jadi, menggugurkan kandungan berarti membuat kandungan menjadi gugur atau menyebabkan menjadi gugur ${ }^{10}$.

Istilah membunuh dapat diartikan menyebabkan kematian atau menghilangkan nyawa. Lalu, membunuh kandungan dapat diartikan yakni menyebabkan kandungan menjadi mati atau menghilangkan nyawa kandungan. Demikian juga, istilah pengguran

\footnotetext{
${ }^{7}$ Sri Widoyati Wiratmo Soekito. Anak dan Wanita Dalam Hukum_(Jakarta: LP3S, 1989), 3.

${ }^{8}$ Departemen Pendidian Nasionnaal. Kamus Besear Bahasa Indonsia (Gramedia Pustaka Utama, 2008), 56.

${ }^{9}$ Kabid Humas Polda Metro Jaya Kombes Pol Yusri Yunus Saat Memimpin Jumpa Pers Pengungkapan Klinik Aborsi di Jakarta Pusat, Selasa (18/8/2020). Bisnis.com.

10 M. Ali Hasan,. Masalah Fiqhiyah Pada Masalah-Masalah kontemporer Hukum Islam (Jakarta: Grafindo Persada , 1998), 84.
} 
kandungan dapat diartikan sebagai lepasnya bagian kandungan dari rahim dan keluar kandungan dari tubuh perempuan yang sedang mengandung. Selanjutnya, pada pembunuhan kandungan dapat diartikan sebagai perbuatan dapat dijatuhi hukuman yang menyebabkan matinya kandungan.

Dilihat dari pendapat para ahli tentang definisi aborsi seperti diatas, maka dapat sekiranya disimpulkan, bahwasanya aborsi merupakan tindakan atau ancaman yang dapat menggugurkan kandungan dengan tindakan tertentu sebelum janin bisa hidup di luar kandungan.

Tindakan aborsi menurut Undang-Undang Hukum Pidana (KUHP) di Indonesia dikategorikan sebagai tindakan kriminal. Undang-Undang Hukum Pidana (KUHP) melarang keras dilakukannya aborsi dengan alasan apapun sebagaimana diatur dalam pasal 346, dan beberapa pasal berkaitan denga aborsi, seperti pasal 283, 299, 349 KUHP.

Dalam ilmu kedokteran istilah-sitilah ini digunakan untuk membedakan aborsi:

1. Abortus Spontanus, abortus yang terjadi dengan sendirinya tanpa ada pengaruh dari luar. Seperti kandungan lemah atau pola makan yang salah dan keracunan.

2. Abotus provocatus, abortus yang dilakukan dengan maksud pertimbangan tertentu, karena kandungan yang tidak di kehendaki adanya atau sengaja digugurkan. Abortus di Indonesia tidak menjadikan aborsi sebagai metode keluarga berencana sebaliknya Indonesia justru mengambil posisi hukum yang paling keras, yaitu melarang semua aborsi untuk semua alasan, kecuali untuk menyelamatkan nyawa ibuAborsi merupakan fenomena sosial yang semakin hari semakin memprihatinkan. Keprihatinan itu bukan tanpa alasan, karena sejauh ini perilaku pengguguran kandungan banyak menimbulkan efek negatif baik untuk diri pelaku maupun pada masyarakat luas.

Diluar negeri, terutama di Amerika Serikat, alasan perempuan melakukan aborsi, yang pertama adalah tidak ingin memiliki anak karena khawatir mengganggu keberlangsungan karier, sekolah dan tanggung jawab lainnya. Yang kedua adalah tidak cukup biaya untuk merawat dan menyekolahkan anak. dan yang terakhir adalah tidak ingin memiliki anak tanpa ayah ${ }^{11}$. Ketiga alasan tersebut sering sekali digunakan perempuan Indonesia, sehingga alasan tersebut membuat perempuan percaya jika membunuh janin di dalam kandungan adalah boleh dan benar. Semua alasan yang diberikan tersebut sebenarnya tidak mendasar, dan sebaliknya alasan yang dipilih menunjukkan bahwa perempuan tidak peduli dan hanya mementingkan dirinya sendiri.

Dilihat dari sudut pandang, perbedaan aborsi yang dilakukan oleh perempuan baik yang sudah menikah dengan yang belum menikah, maka alasan mereka dapat dikelompokkan sebagai berikut ${ }^{12}$ :

1. Pada perempuan yang belum/tidak menikah, alasan melakukan aborsi diantaranya karena masih berusia remaja, pacar tidak mau bertanggung jawab, takut pada orang

\footnotetext{
11 Voaindonesia.com. may 19,2009.

12 Maidin Gullom, 2009, Perlindungan Hukum terhadap Anak dalam Sistem Peradilan Anak di Indonesia (Jakarta: Refika Aditama), 43.
} 
tua, berstatus janda yang hamil di luar nikah, dan berstatus sebagai perempuan simpanan seseorang dan dilarang hamil oleh pasangannya.

2. Pada perempuan yang sudah menikah, alasannya antara lain karena kegagalan alat kontrasepsi, jarak kelahiran yang terlalu rapat, jumlah anak yang terlalu banyak, terlalu tua untuk melahirkan, faktor sosial ekonomi (tidak sanggup lagi membiayai anak-anaknya dan khawatir masa depan anak tidak terjamin), alasan medis, sedang dalam proses perceraian dengan suami, atau karena berstatus sebagai isteri kedua dan suaminya tidak menginginkan kehadiran anak dari dia.

Dari alasan yang ada di atas, dapat disimpulkan bahwa sangat terlihat jelas sebagian besar aborsi bukan hanya di sebabkan kemauan murni, akan tetapi karena rasa takut dengan resiko sosial, takut kepada orang lain baik itu suami, orang tua dan keluarga, karena pakasaan atau kondisi keluarga yang membuatnya tidak berani punya anak lagi dan alasan lainnya ${ }^{13}$.

Sesungguhnya permasalahan aborsi ini tidak asing dalam telinga masyarakat, bahkan angka-angka dari suatu tindak kehatan itu semakin memperhatikan. Dalam pendapat Mardjono Reksodiputro memberikan kontar pedas perihak suatu gejala kriminalitas yang ada pada masyarakat, namun kriminalitas pada tindak pidana aborsi sering kali tidak terungkap, baik oleh media massa atau aparat penegak hukum. Hal demikian seperti biasa dilihat dala data statistik kriminal resmi dengan keadaan fenomena ini disebut sebagai adanya "dark number of crime". Bahkan menurut beliau sebagai fenomena akut yang merupakan kritik pedas dari adanya "selective process in the administration of justice ${ }^{14}$.

Menelisik dari teorinya Anselm Von Feuerbach yakni tentang pendefinisian teorinya psychologische dwang, "apabila setiap orang mengerti dan tahu, bahwa melanggar peraturan hukum itu diancam dengan pidana, maka orang itu mengerti dan tahu juga akan dijatuhi pidana atas kejahatan yang dilakukannya"15. Tanpa kita terjemakan ulang mestinya sudah jelas, mestinya semua orang mengerti akan akibat dari perbuatan yang dia lakukan yakni ganjaran atau sanksi setimpal sebagai balasanya.

Dalam pandangan lain tentang aborsi pada penulisan yang berikatan tentang aborsi tidak atau belum menerapkan kebijakan baru seperti undang-undang perlindungan anak yang juga mengatur tentang permasalahan aborsi, kenapa orientasinya demikian? Hal inilah yang selayaknya patut memdapat kajian akan keberadaan hukum positif yang saling tumpang tindih (overlapping), yang justu nantinya akan menimbulkan kegaduhan. Karena hakikatnya sebuah piranti perundang-

${ }^{13}$ Maya Indah S, Perlindungan Korban: Suatu Perspektif Viktimologi Dan Kriminologi (Jakarta: Kencana, 2014), 65.

14Ibid.,107.

${ }^{15}$ Marlina, Hukum Penitensier (Jakarta: Refika Aditama, 2016), 57. 
undangan itu kembali pada orientasi dan peran-peran badan atau orang berdasarkan latar bekalang keilmuannya dalam sebuah penyusunan sebuah undang-undang ${ }^{16}$.

Sehingga, hal ini layak untuk dikupas dalam sebuah artikel yang mengurai tentang dualisme pandangan aborsi dalam perspektif perundang-undangan, terutama perbandingan landasan yuridis dari dari lex spesialis yakni undang-undang kesehatan dan perlindungan anak, yang keduanya tidak tinggal diam memuat aturan tentang praktik aborsi.

\section{Regulasi Dalam Undang-Undang Kesehatan (UU No. 36 Tahun 2009)}

Abortus Provocatus merupakan istilah lain yang secara resmi dipakai dalam kalangan kedokteran dan hukum. Hadirnya Undang-Undang Republik Indonesia No. 36 Tahun 2009 Tentang Kesehatan, juga mengupas masalah aborsi.

Yakni tertuang dengan jelas pada pasal 75 ayat 1 :

"Setiap orang dilarang melakukan aborsi"

Jauh sebelumnya praktik larangan aborsi ini sudah diatur dalam sebuah regulasi perundang-undang khusus, KUHP sudah memberikan landasan yuridis tanpa adanya pengecualian sama sekali (diperbolehkan aborsi), sebagaimana dalam pasal 299 dan 346349. Pasal-pasal tersebut merupakan landasan kuat penerapan sanksi terhadap praktik aborsi dan dalam subtansi yang lebih luas KUHP yang berorientasi tanpa pandang bulu bagi siapa saja pelanggarnya tanpa memberikan batas alasan diperbolehkan aborsi sebagaimana regulasi saat ini yang ada ${ }^{17}$.

Dengan hadirnya undang-undang kesehatan adala sebuah manifestasi aturan khusus yang mengatur tindak pidana aborsi dengan berdasarkan penerapan asas lex specialis derogate legi generalis, ini akan berdampak pada pengesampingan pada ketentuan pasal 63 ayat (2) KUHP yakni, "berprinsip dimana jika hadirnya undang-undang yang khusus, maka akan mengesampingkan yang sifatnya umum (KUHP/karena berbagai aturan tindak pidana ada disitu)".

Lebih lanjut dalam undang-undang perlindungan anak jaga terdapat praktik penerapan yang sama dengan undang-undang kesehatan yakni pada batasan usia kehamilan seseorang tentunya diatas 6 minggu, karena dalam uu kesehatan menentukan lebih spesifik batas pengguguran usia kandungan.

Konsep hukum positif yang demikian menentukan proses penjatuhan pidana terhadap penguguran janin yang memang tidak diperbolehkan dengan alasan yang kuat seperti diatas. Adanya perbedaan dari berbagai segi hukum sebagai kebijakan perundang-undangan diatas membuktikan bahwa anak, dalam hal ini termasuk janin yang masih dalam kandungan mendapatkan payung hukum sebagai upaya perlindungan hak hidup.

Hal ini sebagaimana tertuang dalam konggres PBB ke 7 yang membicarakan tentang The Prevention Of Crime And The Treatment Of Offender (Milan) Melalui

\footnotetext{
16 Jimmy Asshiddiqie, Perihal Undang-Undang (Jakarta: Gramedia Pustaka, 2010), 118. Pembentukan undang-undnag yang berdasarkan pada landasan sosiologis, yuridis, filosofis, maupun politis akan turut mempengaruhi dalam teknik serta subtansi sebuah pebentukan perundang-undangan.

${ }_{17}$ Berlaku asas dalam hukum yang kemudian kita kenal dengan asas lex specilis derogate legi generalis, artinya apabila sudah ada aturan yang sifatnya khusus/special, maka akan mengesampingkan aturan yang bersifat general/umum yakni KUHP itu sendiri.
} 
Decklaration Of Basic Principle Of Justice For Victim And Abuse Of Power yang kemudian menjadi cikal bakal rancarangan resolusi tentang perlindungan korban, dan akhirnya resmi menjadi Resolusi PBB No. 40/3418.

Pada Sumpah Dokter dan Kode etik kedokteran dengan tegas dan jelas menyebutkan bahwa tindakan seorang dokter melakukan aborsi adalah bertentangan dengan sumpah dan kode etik kedokteran. ${ }^{19}$ Pengecualiannya adalah jika kehamilan itu mengancam jiwa si ibu, yang mengakibatkan efek samping kandungannya yang akan mengalami keguguran oleh karena itu, moralitas, dan etika kedokteran sebenarnya memang tidak membenarkan aborsi sebagai tujuan suatu tindakan.

Aborsi hanya bisa dilakukan seandainya tidak ada jalan lain untuk meyelamatkan jiwa si ibu, itupun dilakukan setelah memenuhi syarat tertentu yang sangat ketat, seperti pertimbangan paling sedikit dari dua orang ahli dalam bidang kandungan/aborsi. Selain itu, harus dilakukan penerapan sarana yang memiliki fasilitas kesehatan yang memadai baikpersonilmaupunperalatanmedis ${ }^{20}$.Pada undangundang kesehatan ini nampak memperketat batasan usia aborsi yakni pada pasal 76 huruf a, yang menegaskan sebelum batas kehamilan berumur 6 minggu, dihitung dari hari pertama masa haid terakhir, kecuali dalam hal kedaruratan medis. Yakni seperti dibawah ini: "sebelum kehamilan berumur 6 (enam) minggu dihitung dari hari pertama haid terakhir, kecuali dalam hal kedaruratan medis"

Kemudian dalam Peraturan Pemerintah No. 61 tahun 2014 tentang Kesehatan Reproduksi juga terdapat pengaturan pelaksanaan yang lebih terinci dari penerapan Undang-Undang Kesehatan, yakni sebagai berikut:

"Tindakan aborsi akibat perkosaan sebagaimana dimaksud pada ayat (1) huruf b hanya dapat dilakukan apabila usia kehamilan paling lama berusia 40 (empat puluh) hari dihitung sejak hari pertama haid terakhir"

Adanya pembatasan tentang usia aborsi yang jelas-jelas ditentukan dalam regulasi diatas adalah semata-mata untuk melindungi terhadap bakal calon janin maupun bagi ibu yang mengandung, tentunya dengan alasan bahwa belum menjadi calon janin yang utuh dalam kandungan serta keselamatan sang ibu bilamana sudah gumpalan bayi (jabang bayi).

Fenoma lain akan muncul berkaitan dengan diperbolehkannya melakukan aborsi serta mendapatkan payung hukum dari undang-undang itu sendiri, dimana pengecualian itu sebagaimana termaktub dalam pasal 75 ayat 2, yaitu:

Larangan sebagaimana dimaksud pada ayat (1) dapat dikecualikan berdasarkan:

a. Indikasi kedaruratan medis yang dideteksi sejak dini kehamilan baik yang mengancam nyawa ibu dan/atau janin yang yang menderita cacat bawaan maupun yang tidak dapat diperbaiki sehingga menyulitkan bayi tersebut hidup diluar kandungan, atau

b. Kehamilan akibat perkosaan yang dapat menyebabkan trauma psikologis bagi korban perkosaan.

\footnotetext{
18 Maya Indah S., Perlindunagn korban: suatu perspektif viktimologi dan kriminologi (Jakarta: Kencana), 24. Yang bersumber dari Report Seventh United Nation Congress on The Prevention Of Crime And The Treatment Of Offenders, Milan, 26-6 September 1985, ( New York: United Nation, 1986), 45. 19 Sebagaimana tertuang dalam Sumpah Dan Kode Etik Kedokteran Indonesia (KODEKI) 20 Ibid.
} 
Banyak yang mengira bahwa Undang-Undang Kesehatan seakan memberikan keleluasaan untuk tindak aborsi, padahal sebenarya tidak demikian adanya. Dalam undang-undang tersebut dengan jelas melarang aborsi kecuali karena indikasi kedaruratan medis dan korban perkosaan, yang juga ditetapkan tentang kehamilan yang boleh diaborsi, sekaligus syarat-syarat yang harus dipenuhi.

Realitas dalam kehidupan pada umumnya pada korban pemerkosaan akan cenderung untuk melakukan jalan pintas aborsi ini, alasannya terkuat adalah depresi atau perasaan psikis malu yang teramat sangat dalm pergaulan masyarakat. Perempuan yang mengalami kejadian seperti ini, kemudian melakukan tindakan pengguguran secara ilegal justru akan menjadi bumerang terhadap dirinya sendiri yaitu bisa terjerat dengan undang-undang yang berlaku. Hal ini adalah suatu momok ibarat pepatah "sudah jatuh tertimbah tangga" meskipun dia hakikatnya adalah korban pemerkosaan. Pada posisi yang demikian, bisa dianggap sebagai pelaku praktik aborsi (melakukan tindak pidana aborsi, dalam teorinya bisa dianggap sebagai doen pleger yakni yang menyuruh lakukan).

Jadi, melakukan tindakan aborsi ini diperbolehkan manakala memenuhi suatu syarat yang ada dalam undang-undang sebagaimana kriteria diatas. Diantaranya tindakan yang manakala mengancam jiwa bagi si ibu atau janin yang menderita kecacatan yang sulit diperbaiki sehingga menyulitkan bayi tersebut hidup diluar kandungan, selanjutnya pada posisi kehamilan akibat korban pemerkosaan yang dapat menyebabkan trauma yang sangat parah serta tindakan konseling sebelum diambil langkah pengaborsian ${ }^{21}$.

\section{Sanksi Aborsi}

Ciri khas model penerapan kebijakan hukum adalah penjatuhan sanksi terhadap pelaku perbuatan yang oleh undang-undang jelas dilarang. Adapun model kebijakan sanksi dalam undang-undang kesehatan terdapat pada pasal 194 undang-undang kesehatan seperti dibawa ini.

Pasal 194 UU No. 36 Tahun 2009

"Setiap orang yang dengan sengaja melakukan aborsi tidak sesuai dengan ketentuan sebagaimana dimaksud dalam Pasal 75 ayat (2) dipidana dengan pidana penjara paling lama 10 (sepuluh) tahun dan denda paling banyak Rp1.000.000.000,00 (satu miliar rupiah)".

Berbicara pada pemberian sanksi pada pelaku aborsi yang umumnya cara ini dilakukan dengan sangat rahasia, tentu akan sangat rumit ditilik dari modus operandi mereka melakukan kejahatan ini. Terlebih pada pengucualian seperti yang diisyaratkan dalam Undang-Undang Kesehatan, hal ini akan melibatkan berbagai pihak yang menjadi eksekutor tindakan aborsi. Pada umumnya praktik ilegal seperti ini, pelaku tidak mempunyai pengetahuan untuk melakukan aborsi, pada akhirnya menyeret pelaku-pelaku lain untuk bisa dimintai tanggung jawab.

${ }^{21}$ Kusmaryanto, Kontroversi Aborsi (Jakarta: Gramedia Widiasarana Indonesia). 


\section{Regulasi Dalam Undang-Undang Perlindungan Anak (UU No. 35 Tahun 2014)}

Abortus Provocatus atau aborsi telah menjadi pemasalahan yang serius dalam tatanan kehidupan masyarakat kita, nampak tiap tahun terus mengalami peningkatan terhadap tindakan ilegal ini. Indonesia merupakan salah satu negara yang tidak melegalkan praktik aborsi. Permasalahan aborsi sudah menjadi perbincangan secara internasional dan tidak hanya sebatas wacana nasional belaka.

Tidak cukup Undang-Undang Kesehatan saja yang mengatur perihal praktik aborsi di Indonesia ini, akan tetapi permasalahan/perbuatan aborsi ini juga diatur dalam Undang-Undang Perlindungan Anak. Jadi, permalasahan aborsi ini nampak kompleks sehingga perlu adanya pengaturan yang lebih spesifik kiranya ${ }^{22}$.

Dalam undang-undang perlindungan anak ini permasalahan aborsi diatur tepatnya dalam pasal 45 A sebagai berikut,

"Setiap Orang dilarang melakukan aborsi terhadap Anak yang masih dalam kandungan, kecuali dengan alasan dan tata cara yang dibenarkan sesuai dengan ketentuan peraturan perundang-undangan"

Jadi, dalam ketentuan undang-undang perlindungan anak juga memberikan payung hukum terhadap larangan praktik aborsi. Namun yang menarik disini adalah letak perumusannya yakni pada perbuatan pelaku yakni harus sudah cukup memenehi umur, dengan kata lain lain sudah dewasa atau diatas umur 21 tahun, yang bisa dianggap sebagai subyek hukumnya.

Dalam usaha penyelenggaraan perlindungan anak yang berasaskan Pancasila dan berlandaskan Undang-Undang Dasar Negara Republik Indonesia Tahun 1945 serta prinsip-prinsip dasar konvensi hak-hak anak salah satunya meliputi hak untuk hidup, kelangsungan hidup, dan perkembangan ${ }^{23}$.

Anak yang dimaksud di sini adalah seseorang yang belum berusia 18 tahun, termasuk anak yang masih dalam kandungan.

Perlindungan ini juga diatur dalam Pasal 4 UU Perlindungan Anak:

"Setiap anak berhak untuk dapat hidup, tumbuh, berkembang, dan berpartisipasi secara wajar sesuai dengan harkat dan martabat kemanusiaan, serta mendapat perlindungan dari kekerasan dan diskriminasi."

Kemudian atas dasar hal tersebut, kewajiban negaralah untuk menjaga dan melindungi hak hidup setiap warganya, melalui alat-alat negara penegak hukum akan bertindak apabila diketahui terjadi penghilangan hak hidup manusia.

Sebagaimana diketahui, bahwa dalam hukum positif yang berlaku saat ini (yang berinduk pada KUHP), permasalahan perumusan subyek tindak pidana kerap kali menyerap istilah-istilah asing yang lagi berlaku popular. Istilah aborsi sendiri pada awalnya tidak ditemui dalam KUHP sebagai induk perundang-undangan, sebagaimana termuat dalam pasal $346^{24}$. Arti perumusan seperti ini tidak manjadi

\footnotetext{
22 Soedarto, Hukum Pidana (Semarang, Balai Yayasan Soedarto, 2010), 56.

${ }^{23}$ Convention On The Rights of The Child (Konvensi Tentang Hak-hak Anak)/Konvensi-Konvensi PBB Tentang Anak. Akibat ratifikasi maka keluarlah kepres Kepres RI Nomer 36 Tahun 1990.

24 Prinsip Harmonisasi Kesatuan Sistem Dalam Kebijakan Formulasi ketentuan pidana dan masalah kualifikasi delik, hal ini karena ada dua perbenturan rumusan masalah tindak pidana dalam
} 
permasalahan dalam pergeseran sebuah arti ataupun kandungan isi pasal yang dimaksud, sebagaiman pasal 346 dengan istilah aborsi bila di bedah dari segi filologi bahasa tetap mempunyai makna yang sama ${ }^{25}$.

Berangkat pada gagasan atau prinsip harmonisasi kesatuan sistem, terhadap berlakunya UU khusus diluar KUHP, seyogya berorientasi pada pedoman yang ada dalam sistem induk yani kuhp itu sendiri serta bukan sebagai bangunan liar yang keluar dari sistem induknya (kuhp). ${ }^{26}$

Terlepas dari dari orientasi sistem KUHP sebagai induk, regulasi dalam perundang-undangan aborsi, khusus pada Undang-Undang Perlindungan Anak adalah mengenai batasan waktu aborsi itu dilakukan. Dalam hal ini, tidak boleh serta merta suatu tindak pidana aborsi langsung dijerat dengan Undang-Undang Perlindungan Anak ataupun Undang-Undang Kesehatan.

Redaksi yang terdapat dalam pasal 45 A Undang-Undang Perlindungan Anak tidak secara jelas memberikan batasan waktu yang spesifik, kapan perbuatan itu dilakukan. Namun, melihat pada konteks isi pada pasal 76 huruf a UU Kesehatan yang secara eksplisit jelas, maka bisa ditarik sebuah kesimpulan bahwa batasan waktu yang dimaksud setelah batas waktu yang ada pada pasal 76 huruf a itu habis atau setelah berumur 6 (enam) minggu bila dihitung dari hari terakir haid.

Setelah habis penghitungan yang ada dala pasal 45 A tersebut, maka prinsip penjatuhan sanksi masuk kategori pada regulasi undang-undang perlindungan anak (karena tidak menyebutkan batasan waktu pengguguran yang jelas).

Dari analisis diatas, tentu sudah cukup memberikan gambaran tentang bagaimana menentukan suatu rumusan sanki yang terdapat dalam sebuah perundangundang bila mana keduanya sama-sama menerapkan rumusan delik (tindak pidana) yang sama, yakni dalam hal ini terkait delik aborsi. ${ }^{27}$ Maka sebagai landasan prinsip pengaturan tersebut haruslah dicari titik benang merahnya dari kedua regulasi tersebut, sebagaimana tertera pada klausula pasal 76 huruf a Undang-Undang Kesehatan dan pasal 45 A Undang-Undang Perlindungan Anak.

penerapan sebuah kebijakan seperti muatan dalam tema diatas yakni antara undang-undang Kesehatan dan perlindungan anak.

${ }^{25}$ Seputar perumusan tindak pidana (subyeknya), kerap kali kita tertinggal dalam penerapan suatu kejahatan dan kemudian baru mengintroduksir ketika negra lain sudah mengeluarkan produk perundang-undangan baru (baru meratifikasi dikemudian hari).

${ }_{26}$ Barda Nawawi Arif, Kebijakan Formulasi Ketentuan Pidana Dalam Peraturan Perundang-Undangan (Semarang: Pustaka Magister, 2012),17-19. Oleh Jan Remmilink, Hukum Pidana, Komentar Atas PasalPasal Terpenting Dari Kuhp Belanda Dan Padanannya Dalam Kuhp Indonesia. KUHP Indonesia yang berlaku sejak 1918 pun pada prinsipnya mengenal dua kategori, yakni kejahatan (misdrijven) dan pelanggaran (overtredingan).

${ }^{27}$ Kedua rumusan delik seperti ini menitikberatkan pada hal-hal yang spesifik, dalam arti dicari pembeda diantara kedua undang-undang ketika dipakai untuk menjerat pelaku, ini adalah suatu prinsip dalam penerapan kebijakan apabila dalam suatu tindak pidana kedua undang-undang yang ada sama-sama mengatur. Sangat kebetulan pada tindakan aborsi ini sama-sama diatur dalam jenis undang-undang spesialis, adanya pembeda dalam isi undang-undang yang dipakai berguna menghindari terjadi overlapping (tumpang tindih) dimana para penegak hukum menerapkan hukumnya sesuai fakta sosio yuridis. 


\section{Sanksi Aborsi}

Undang-Undang Perlindungan Anak juga memberikan ancaman bagi pelaku sebagaimana undang-undang kesehatan terhadap larangan aborsi. Sebagaimana dalam ketentuan pasal 77 A UU No. 35 Tahun 2014 sebagai berikut.

Pasal 77A

1. Setiap Orang yang dengan sengaja melakukan aborsi terhadap Anak yang masih dalam kandungan dengan alasan dan tata cara yang tidak dibenarkan oleh ketentuan peraturan perundang-undangan sebagaimana dimaksud dalam Pasal 45A, dipidana dengan pidana penjara paling lama 10 (sepuluh) tahun dan denda paling banyak Rp1.000.000.000, (satu miliar rupiah).

2. Tindak pidana sebagaimana dimaksud pada ayat (1) adalah kejahatan.

Dalam Undang-Undang Perlindungan Anak dikenakannnya sanksi aborsi terlihat tidak terlalu dini sebagaimana dalam Undang-Undang Kesehatan, sekalipun hal ini yang menjadi petunjuk nanti dalam penentuan terhadap pilahan mana apabila seseorang melakukan tindak pidana aborsi. Fakta lain dalam Undang-Undang Perlindungan Anak secara otamatis menutup ruang bagi pelaku anak yang tidak bisa di jerat (seumpama pelaku aborsi adalah anak) dengan memakai jenis Undang-Undang Perlindungan Anak ini ${ }^{28}$.

\section{KESIMPULAN}

Dengan Kebijakan perundang-undangan yang ada hendaknya memberikan arah pedoman serta usaha pencegahan terhadap tindakan praktik aborsi. Hal ini baik menjawab dari dua segi penerapan kebijakan yang mempuyai model batasan yang signifikan berbeda. Berkaitan dengan praktik aborsi yang semakin menjurus menjadi kebiasaan hendaknya menjadi suatu ancaman bagi siapa saja yang menjadi pelaku ataupun klinik ilegal yang bersedia memberikan kesempatan melakukan tindakan terkutuk ini.

Regulasi dalam Undang-Undang Kesehatan bahwa sesungguhnya tindakan aborsi sangat dilarang, sebagaimana tertuang dalam pasal 75 ayat (1) serta mengancam bagi siapa saja yang melakukan tindak pidana tersebut. Ancaman itu tertuang dalam pasal 194 Undang-Undang Kesehatan, yakni sanksi pidananya paling lama 10 dan denda paling banyak 1 milyar. Tentang alasan yang diperbolehkan melakukan aborsi dalam undang-undang memaparkan, bahwa yang pertama adalah karena kedaruratan medis dan yang kedua adalah kehamilan yang diakibatkan pemerkosaan. Hal demikian diatas juga dipertegas Dalam Peraturan Pemerintah No 61 Tahun 2014 Tentang Kesehatan Reproduksi yang diatur didalamnya cukup detail. Kemudian memberi batasan waktu jelas yaitu sebelum usia kehamilan berumur 6 minggu, dihitung dari terakhir masa haid.

${ }^{28}$ Bertens K, Aborsi Sebagai Masalah Etika(Jakarta: Grasindo, 2002), 21. 
Pada Undang-Undang Perlindungan Anak permasalahan aborsi juga mendapat payung hukum yang jelas sebagaimana pasal 45A dengan tegas melarang aborsi. Lalu, terkait dengan ancaman yang diberikan dapat kita lihat pasal 77A, sama persis seperti yang diancamkan dalam Undang-Undang Kesehatan. Pembeda dari kedua kebijakan regulasi perundang-undangan diatas yakni pada Undang-Undang Perlindungan Anak tidak memasukkan secara jelas mengenai batasan waktu tentang atau usia kapan dilakukan tindak aborsi, hal ini sebagaimana adalam undang-undang kesehatan. Sehingga, hal ini menjadi petunjuk dikemudian hari terhadap tindak pidana aborsi serta penerapan (memakai) apakah memakai Undang-Undang Kesehatan atau UndangUndang Perlindungan Anak yang dapat dilihat dari batasan waktu pelaksanaan perbuatan aborsi itu dilakukan.

Sebagai pedoman dari kedua jenis perundang-undangan lex specialis tersebut sama-sama mengatur perihal larangan aborsi yang harus ditentukan spesifik batasan waktu yang menjadi bahan analisisnya. Disisi pengamatan lain dari Undang-Undang Perlindungan Anak fokus pada masalah subyek pelakunya yang mengharuskan orang dewasa, sedikit berbeda pada Undang-Undang Kesehatan memungkinkan anak bisa terjerat menjadi subyek pelakunya.

\section{DAFTAR PUSTAKA}

Bertens K. Aborsi Sebagai Masalah Etika . Jakarta: Grasindo, 2002.

Bismar Siregar dan Abdul Hakim Garuda Nusantara. Hukum dan hak-hak anak. Jakarta: Rajawali, 2010.

Chandra. Tanpa Indikasi Medis Ibu, Aborsi Sama dengan Kriminal.Lifestyle. Lilien Eka, 2006.

Chazawi, Adami. Stelsel Pidana, Tindak Pidana, Teori-Teori Pemidanaan, dan Batas Berlakunya Hukum Pidana. Jakarta: Raja Grafindo, 2005

Hasan, Ali. Masalah Fighiyah Pada Masalah-Masalah kontemporer Hukum Islam. Jakarta: Grafindo Persada, 1998.

Istibsjaroh. Menimbang Hukum Pornografi, Pornoaksi, dan Aborsi dalam Perspektif Islam. Surabaya: IAIN Sunan Ampel Press, 2007.

Joni, Muhammad. Aspek Hukum Perlindungan Anak: Dalam Perspektif Konvensi Hak Anak. Bandung: PT. Citra Aditya Bakti, 1999.

Kamus Besar Bahasa Indonesia. Jakarta: Balai Pustaka, 1988.

Kusmaryanto. Kontroversi Abors. Jakarta: Gramedia Widi Sarana Indonesia, 2002.

Maidin Gullom. Perlindungan Hukum terhadap Anak dalam Sistem Peradilan Anak di Indonesia Jakarta: Refika Aditama, 2009.

Muladi dan Barda Nawawi Arief. Teori-teori dan Kebijakan Pidana. Bandung: Alumni, 1998.

Mulyadi, Lilik. Kapita selekta Hukum Pidana Kriminologi dan Viktimologi. Jakarta: Djambatan. 2004.

Nasution, Khoiruddin. Pandangan Islam Tentang Aborsi. Musawa: Jurnal Studi Gender Dan Islam, Vol 2, Yogyakarta: UIN Sunan Kalijaga Yogyakarta, 2003. 
Nawawi Arif, Barda. Perkembangan Asas Hukum Pidana Indonesia. Bandung: PT. Pustaka Magister, 2008.

Nawawi Arif, Barda. Perkembangan Sistem Pemidanaan di Indonesia. Semarang: PT. Pustaka Magister, 2008.

Nawawi Arif, Barda. RUU KUHP BARU: Sebuah Restrukturisasi Sistem Hukum Pidana Indonesia, Semarang; Pustaka Magister, 2008.

Nawawi Arif, Barda. Kebijakan Formulasi: Ketentuan Pidana Dalam Peraturan PerundangUndangan. Semarang: Pustaka Magister, 2012.

Rukmini, Mien. Laporan Akhir Penelitian Tentang Aspek Hukum Pelaksanaan Aborsi Akibat Perkosaan. Jakarta: Badan Pembinaan Hukum Nasional (BPHN) Departemen Kehakiman dan HAM, 2002.

Prinst, Darwin. Hukum Anak Indonesia. Jakarta: Citra Aditya Bakti, 1997.

Sudarto. Kapita Selekta Hukum Pidana. Bandung: Alumni, 1991.

Soekamto, Sarjono. Antropologi Hukum. Jakarta: Renika Cipta, 2000.

Soekito, Sri Widoyati Wiratmo. Anak dan Wanita Dalam Hukum L LP3S, Jakarta: LP3S, 1989.

Soemitro, Irma Setyowati. Aspek Hukum Perlindungan Anak. Jakarta: Bumi Aksara, 1990.

Sudarto. Hukum Pidana I. Semarang: Yayasan Sudarto, 1990.

Soeaidy, Sholeh dan Zulkhoir. Dasar Hukum Perlindungan Anak. Jakarta: Novindo Pustaka Mandiri, 2001.

Wadong, Maulana Hassa. Advokasi dan Hukum Perlindungan Anak. Jakarta: Gramedia Wirasarana Indonesia, 2000. 